\title{
YEAR CYCLE OF AUSTROPOTAMOBIUS TORRENTIUM (SCHRANK) IN STREAMS ON MEDVEDNICA MOUNTAIN (CROATIA).
}

\author{
I. MAGUIRE, R. ERBEN, G.I.V. KLOBUČAR, J. LAJTNER
}

Department of Zoology, Faculty of Science, University of Zagreb, Rooseveltov trg 6, 10000 ZAGREB, Croatia.

\begin{abstract}
We studied life cycle of stone crayfish for 18 months in three streams on Medvednica Mountain, located above city of Zagreb. Sampling of animals was carried out with baited traps twice a month and various physiological functions were recorded. Sex ratio of trapped crayfish was $1: 1$, but it fluctuated during the year. Animals were active from early spring until the beginning of November when their activities significantly decreased. In this period we noticed three peaks of higher activity. The first one after winter starvation in March, the second one after egg hatching (June/July) and the third one during mating period (end of September - beginning of November). The maximal recorded weight for female was $38 \mathrm{~g}$ while the heaviest male was $55 \mathrm{~g}$. The longest female was $9.28 \mathrm{~cm}$ and male $10.30 \mathrm{~cm}$. Development of glair glands started from the end of July, mating occurred at the end of October and the juveniles hatched until mid-June. Freshly moulted animals were found from mid-May until mid-October. Main injuries were claw and limb loss. We noticed the presence of burn spot disease and Branchiobdella parasita Henle within studied populations. Correlation with five different physico-chemical parameters of water showed that animals' activity is positively correlated to water temperature, conductivity, $\mathrm{pH}$ and hardness and negatively to oxygen concentration.
\end{abstract} Croatia.

Key-words: Austropotamobius torrentium, stone crayfish, year cycle, ecology,

\section{LE CYCLE ANNUEL D' AUSTROPOTAMOBIUS TORRENTIUM (SCHRANK) DANS TROIS RUISSEAUX DE LA MONTAGNE MEDVEDNICA (CROATIE).}

\section{RÉSUMÉ}

Nous avons étudié durant 18 mois le cycle annuel de l'écrevisse des torrents (Austropotamobius torrentium) dans trois ruisseaux de la montagne Medvednica au-dessus de la cité Zagreb. L'échantillonnage des animaux a été fait par nasses deux fois par mois et différentes fonctions physiologiques ont été enregistrées. La proportion du sexe est de $1: 1$, les valeurs ont cependant fluctué au cours de l'année. Les animaux sont actifs à partir 
du printemps jusqu'au mois de novembre, lorsque leur activité diminue significativement. Durant cette période, nous avons observé trois sommets d'activité intense. Le premier se situe après la famine de l'hiver (en mars), le second après l'éclosion des œufs (juin/juillet) et le troisième pendant la période de reproduction (fin septembre - début novembre). La femelle la plus lourde pèse $38 \mathrm{~g}$, le mâle le plus lourd $55 \mathrm{~g}$. La femelle la plus longue mesure $9,28 \mathrm{~cm}$, le mâle $10,30 \mathrm{~cm}$. Le développement des glandes glaires commence à partir du mois de juillet, la reproduction a lieu fin octobre et les juvéniles éclosent jusqu'a la mi-juin. Les animaux en mue ont été repérés de mi-mai a mi-octobre. Les blessures qui apparaissent principalement sont la perte de pinces et de pattes. Nous avons observé dans ces populations la présence de «burn spot disease » et de Branchiobdella parasita Henle. La corrélation avec cinq paramètres physico-chimiques de l'eau montre que l'activité des animaux est positivement corrélée à la température de l'eau, la conductivité, le $\mathrm{pH}$ et l'alcalinité, et négativement corrélée à la concentration en oxygène.

Mots-clés : Austropotamobius torrentium, écrevisse des torrents, cycle annuel, écologie, Croatie.

\section{INTRODUCTION}

Four crayfish species from the family Astacidae are found in Croatia: the noble crayfish (Astacus astacus, Linnaeus), Turkish crayfish (Astacus leptodactylus, Eschscholtz), the white-clawed crayfish (Austropotamobius pallipes, Lereboullet) and the stone crayfish (Austropotamobius torrentium, Schrank). The native species are protected by Croatian law (NARODNE NOVINE 30/1994, 76/1998) and treated as endangered. Any fishing is prohibited but, due to illegal catching, noble crayfish can be found at some markets.

Nowadays populations are remaining of the ones devastated by crayfish plague at the end of $19^{\text {th }}$ and beginning of $20^{\text {th }}$ century (ŠULGAJ, 1937; BUDIHNA, 1991). River regulation, water pollution and increased use of fertilizers and pesticides also influence their abundance. Detailed distribution of freshwater crayfish in Croatia has not yet been studied, but some approximate data are existing (MAGUIRE, 2002).

A. astacus is distributed within the continental part of Croatia, forming both river and lake populations. It can be also found in some watercourses on the Adriatic coast. Authors do not know the origin of coastal populations but it is supposed that the noble crayfish was introduced there for consumption purposes.

A. leptodactylus is found in ponds, swamps and rivers in Slavonia (eastern Croatia).

A. pallipes is distributed in Lika, Istria, Dalmatia and on some islands in the Adriatic Sea (south and south-west Croatia).

A. torrentium can be found in streams at higher altitudes within the continental part of Croatia.

Data about the stone crayfish in Croatia are scarce and there are not many data published about them in general (BOHL, 1987a; LAURENT, 1988; TROSCHEL et al., 1995; RENZ and BREITHAUPT, 2000). Their small size (a maximum length of about $11 \mathrm{~cm}$ and a maximum weight of about $70 \mathrm{~g}$ (TROSCHEL and DEHUS, 1993)) makes them unsuitable for intensive commercial exploitation (LAURENT, 1988) which is probably one of the reasons why they have been rarely studied. On the other side the positive consequence of not being a commercially attractive species is that their actual distribution in Europe is uninfluenced by human translocations (TROSCHEL et al., 1995; KAPPUS et al., 1999). 
A. torrentium mainly inhabits headwater sections of small fast running brooks (KAPPUS et al., 1999), but also forms lake populations (VORBURGER and RIBI, 1999; RENZ and BREITHAUPT, 2000). Coexistence with other species in the same water body was observed (BOHL, 1987a; LAURENT, 1988; STUCKI and ROMER, 2001; MAGUIRE, 2002). The degree to which the distribution area of two species overlaps mainly depends on their preference for the habitat type (BOHL, 1987a; STUCKI and ROMER, 2001). The most important factor determining a crayfish choice of habitat is the substrate on the bottom of the water-body (CAPELLI and MAGNUSSON, 1975; LODGE and HILL, 1994) which in the case of the stone crayfish is indicated by its name. Because its preferred substrate is not optimal for other species of freshwater crayfish, especially alien ones that carry Aphanomyces astaci, $A$. torrentium seems to be not so heavily affected by the crayfish plague as other native European crayfish (BOHL, 1999; RENZ and BREITHAUPT, 2000). The stone crayfish's disappearance is due to the human impact on their natural habitats that are usually isolated and often separated by habitat destruction and barriers. Usually, when a local population dissapears, no natural recolonisation occurs (BOHL, 1997).

The main objective of this study was to describe a year cycle of A. torrentium. Data on sex ratio, weight and the total length of the animals, development of internal and external eggs, time of mating, hatching of eggs, time of moulting, injuries, visible diseases and epibionts on this small astacid species were collected during 18 months. Correlations with some physico-chemical characteristics of the water were calculated as well.

\section{MATERIAL AND METHODS}

Populations of $A$. torrentium were studied from October 1998 until April 2000 in three streams: Sarni, Kraljevec and Mrzlak (250 m, 400 m, 300 m above sea-level, respectively) all situated on Medvednica mountain, above Zagreb $\left(16^{\circ} \mathrm{E}\right.$ and $\left.46^{\circ} \mathrm{N}\right)$ (Figure 1). The width of the streams and their water level fluctuated within the course of the year. All three streams have shallow shores and are situated in the beech or beech-chestnut forests. The floor of the streams consists of stones, rocks and pebbles with plenty of fallen trees and roots, offering a variety of hiding places for crayfish.

The sites were visited twice a month and usually 25 traps were exposed at approximately $10 \mathrm{~m}$ intervals along the shorelines, under stones or tree roots. Traps were made of PVC bottles (cylindrical shape) with funnel entrances (made from plastic net, mesh size $=2 \mathrm{~mm}$ ) at both ends. Traps were baited with fish or pig liver and were left in the stream over night. Trapped crayfish were checked for sex, moulting state (soft-shell/ hard-shell), cheliped and limb loss, injuries, visible diseases and epibionts. Branchiobdellidans were determined according to KARAMAN (1967). Weight and total length, from the tip of the rostrum to the end of the telson, were measured. Females were checked for reproductive state (activated glair glands, spermatophores attached to the abdomen, eggs or hatched juveniles). The development of internal eggs was observed by bending the females bodies and inspecting the colour of the eggs in the gap between the carapace and abdomen. Internal egg stages were noted as yellow or brown-green. External eggs were counted and their diameter was measured. After examination, crayfish were released back into the water.

For each sampling date, water temperature, conductivity, oxygen concentration as well as $\mathrm{pH}$, were recorded in the field, while water hardness was measured in the laboratory (APHA, 1985).

For statistical analyses (descriptive statistic; Pearson correlation) we used Microsoft Excel program. 


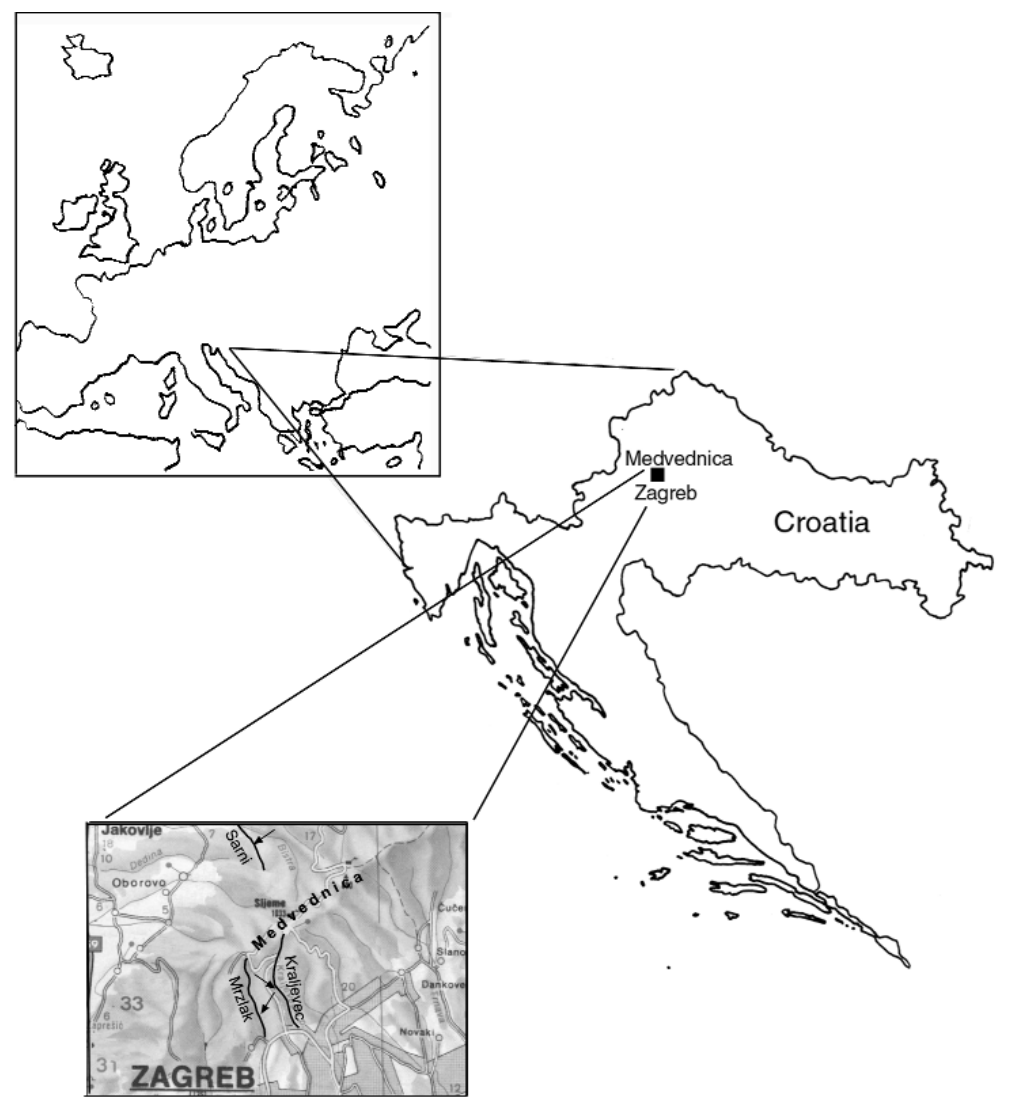

Figure 1

Map of investigated area with positions of study sites.

\section{Figure 1}

Carte de la région étudiée avec les sites d'étude marqués.

\section{RESULTS}

Description of measured physico-chemical parameters for the three study sites is given in Table I.

\section{SARNI STREAM}

We found positive correlations between the number of animals caught and the water temperature $(r=0.611)$, water hardness $(r=0.516)$, conductivity $(r=0.352)$ and $p H$ $(r=0.168)$, negative correlation was recorded between animal number and oxygen concentration $(r=-0.331)$.

We caught 236 animals in all (123 males and 113 females; sex ratio 1.09:1). The number of observed males and females fluctuated throughout the year according to their life cycle (Figure 2). There was no crayfish activity recorded when the temperature was below $6.6^{\circ} \mathrm{C}$. It seems that males were more active during the time when females were berried. Females were more active after hatching and therefore more frequently caught. The heaviest male caught was $46 \mathrm{~g}$ and the heaviest female was $26 \mathrm{~g}$. The longest male we caught was $9.94 \mathrm{~cm}$ long and the longest female was $8.60 \mathrm{~cm}$ long. We found a strong positive correlation between animals' length and weight $(r=0.912)$. 
Table I

Physico-chemical parameters of water and water depth. Orientation and altitude of the study site.

\section{Tableau I}

Paramètres physico-chimiques de l'eau et profondeur des ruisseaux. Orientation et altitude des sites d'étude.

\begin{tabular}{|c|c|c|c|c|c|c|}
\hline & \multicolumn{2}{|c|}{ Sarni } & \multicolumn{2}{|c|}{ Kraljevec } & \multicolumn{2}{|c|}{ Mrzlak } \\
\hline & range & mean $\pm S D$ & range & mean $\pm S D$ & range & mean \pm SD \\
\hline 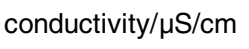 & $139.3-47$ & $144.2 \pm 2.6$ & $139.2-146.6$ & $143.6 \pm 2.6$ & $138.3-146.7$ & $143.5 \pm 2.5$ \\
\hline $\mathrm{O}_{2} / \mathrm{mg} / \mathrm{l}$ & $6.8-13.1$ & $10.8 \pm 1.8$ & $7.8-14.5$ & $10.9 \pm 1.6$ & $7.7-12.4$ & $10.3 \pm 1.3$ \\
\hline $\mathrm{T} /{ }^{\circ} \mathrm{C}$ & $1-18.9$ & $9.8 \pm 5.1$ & $3.1-16.6$ & $9.8 \pm 4.1$ & $2.9-22$ & $10.7 \pm 5.2$ \\
\hline $\mathrm{pH}$ & $6.1-8.2$ & $7.4 \pm 0.5$ & $6.5-8.6$ & $8.0 \pm 0.4$ & $6.4-8.7$ & $8.1 \pm 0.4$ \\
\hline $\mathrm{mg} \mathrm{CaCO}_{3} / \mathrm{l}$ & $50-100$ & $73.6 \pm 7.9$ & $100-190$ & $114.3 \pm 17.6$ & $145-200$ & $168.8 \pm 14.7$ \\
\hline exposure & \multicolumn{2}{|c|}{ north } & \multicolumn{2}{|c|}{ south } & \multicolumn{2}{|c|}{ south } \\
\hline depth/cm & \multicolumn{2}{|c|}{$34 \pm 19$} & \multicolumn{2}{|c|}{$25 \pm 9$} & \multicolumn{2}{|c|}{$20 \pm 16$} \\
\hline altitude/m & \multicolumn{2}{|c|}{250} & \multicolumn{2}{|c|}{400} & \multicolumn{2}{|c|}{300} \\
\hline
\end{tabular}

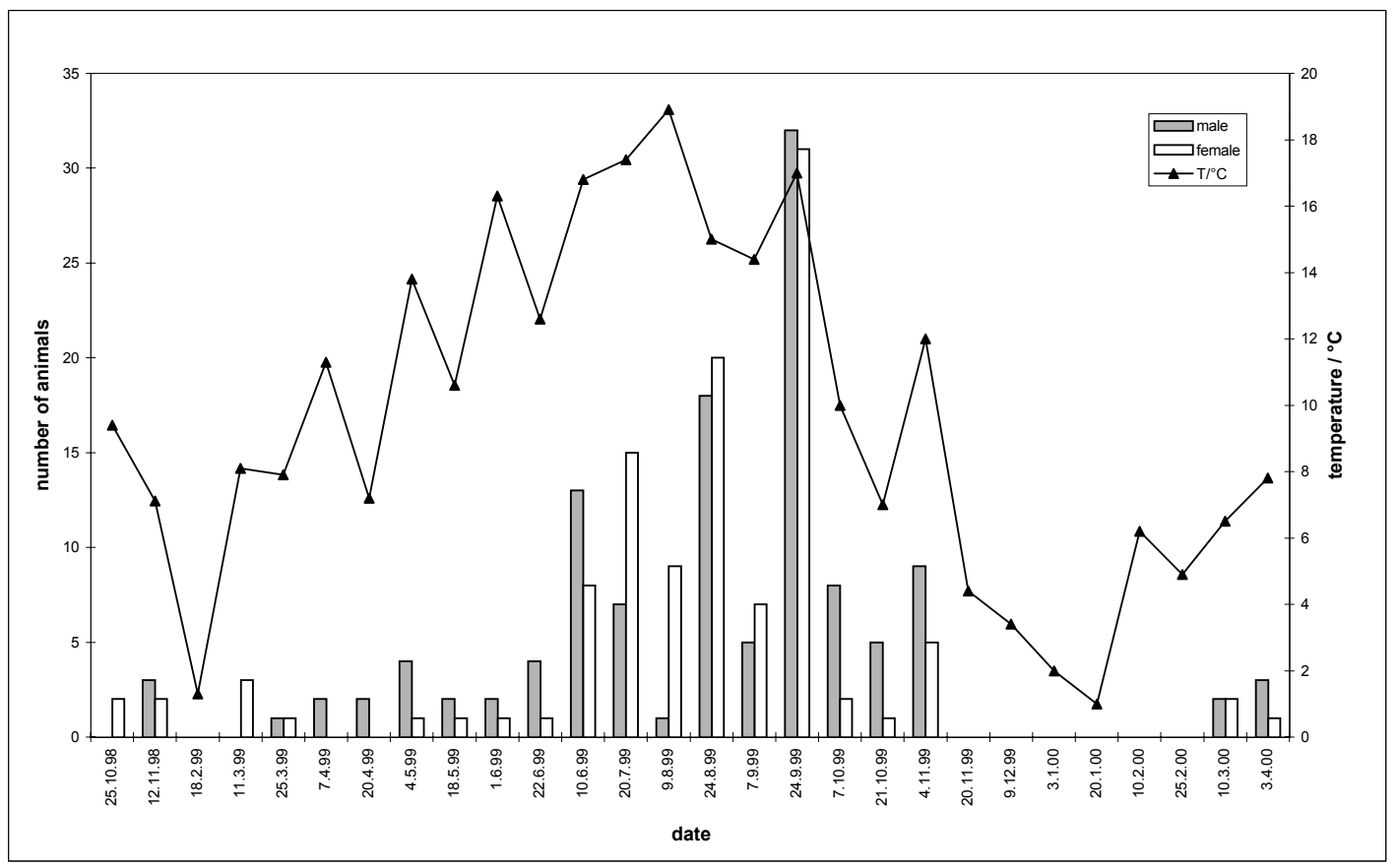

Figure 2

Relation between number of $\boldsymbol{A}$. torrentium caught in Sarni stream per month and water temperature.

Figure 2

Relation entre le nombre d'A. torrentium capturées par mois dans le ruisseau Sarni et la température. 
Freshly moulted animals were caught for the first time on the $1^{\text {st }}$ of June, and for the last time at the beginning of October (Table II).

Development of the glair glands in females started in August $\left(24^{\text {th }}\right)$, and mature testes were recorded at the beginning of October.

Yellow (internal) eggs were noticed for the first time on the $9^{\text {th }}$ of August, browngreen eggs on the $24^{\text {th }}$ of September and external eggs on the $4^{\text {th }}$ of November. On that occasion we also found spermatophores attached to females abdomen. On the $1^{\text {st }}$ of June we caught a female with eggs for the last time (Table II).

\section{Table II}

Year cycle of some physiological functions per months.

\section{Tableau II}

Cycle annuel des fonctions physiologiques par mois.

\begin{tabular}{|c|c|c|c|c|c|c|c|c|c|c|c|c|}
\hline site & & & & & & & nth & & & & & \\
\hline function & 1 & 2 & 3 & 4 & 5 & 6 & 7 & 8 & 9 & 10 & 11 & 12 \\
\hline SARNI & & & & & & & & & & & & \\
\hline activity & & & & & & & & & & & & \\
\hline moulting & & & & & & & & & & & & \\
\hline mature testes & & & & & & & & & & & & \\
\hline glair glands & & & & & & & & & & & & \\
\hline yellow eggs & & & & & & & & & & & & \\
\hline brown eggs & & & & & & & & & & & & \\
\hline external eggs & & & & & & & & & & & & \\
\hline KRALJEVEC & & & & & & & & & & & & \\
\hline activity & & & & & & & & & & & & \\
\hline moulting & & & & & & & & & & & & \\
\hline mature testes & & & & & & & & & & & & \\
\hline glair glands & & & & & & & & & & & & \\
\hline yellow eggs & & & & & & & & & & & & \\
\hline brown eggs & & & & & & & & & & & & \\
\hline external eggs & & & & & & & & & & & & \\
\hline MRZLAK & & & & & & & & & & & & \\
\hline activity & & & & & & & & & & & & \\
\hline moulting & & & & & & & & & & & & \\
\hline mature testes & & & & & & & & & & & & \\
\hline glair glands & & & & & & & & & & & & \\
\hline yellow eggs & & & & & & & & & & & & \\
\hline brown eggs & & & & & & & & & & & & \\
\hline external eggs & & & & & & & & & & & & \\
\hline
\end{tabular}

present in the part of the month
absent
present


From 113 females trapped, $6(5.3 \%)$ were found with eggs and $42(37.2 \%)$ with developed glair glands.

The smallest female with activated glair glands was $6.08 \mathrm{~cm}$ long and the smallest carrying eggs was $6.55 \mathrm{~cm}$ long.

The mean diameter of pleopodal eggs was $2.88 \mathrm{~mm}$ (ranged from 2.7 to $3 \mathrm{~mm}$ ) and mean number of eggs per female was 63 (ranged from 4 to 100). A strong positive correlation existed between the females length and the number of eggs $(r=0.915)$ and a negative one between the number of eggs and their diameter $(r=-0.278)$.

$32.77 \%$ of population caught suffered from limb or cheliped loss, $21.74 \%$ had signs of burn spot disease and on $15.74 \%$ we found epibionts Branchiobdella parasita (Figure 3).

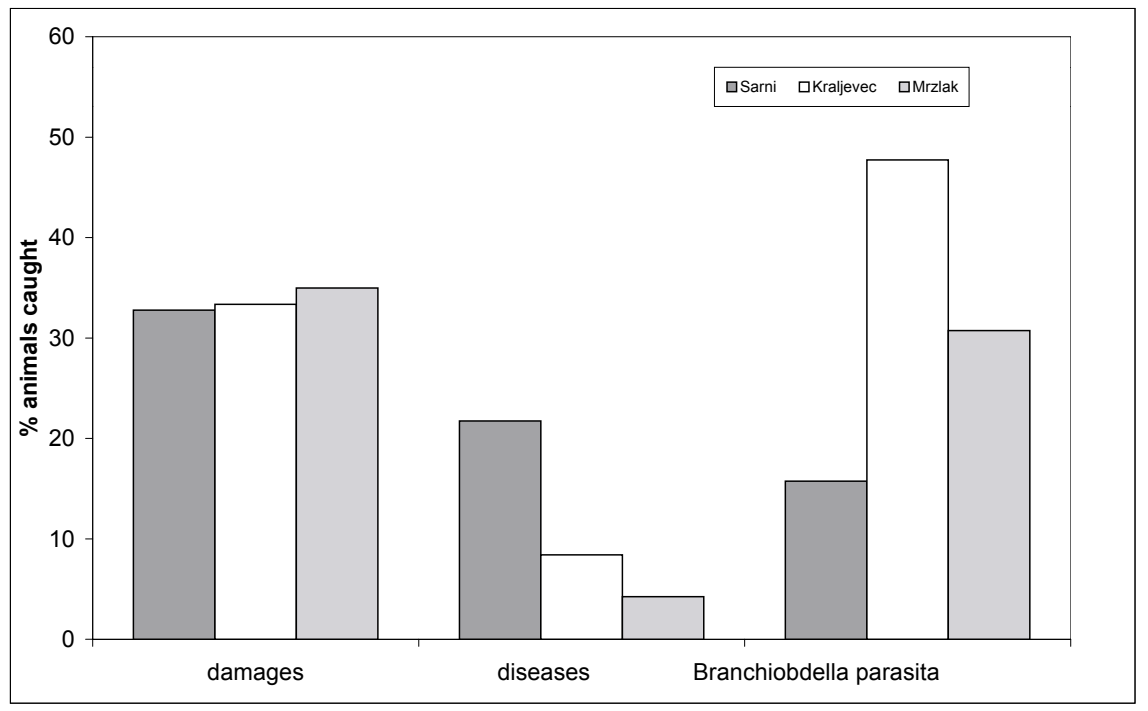

\section{Figure 3}

Percentages of animals caught with damages, diseases and epibionts.

Figure 3

Pourcentage d'animaux blessés, malades et avec épibionts.

\section{KRALJEVEC STREAM}

We found positive correlations between the number of animals caught and water temperature $(r=0.798)$, water hardness $(r=0.682)$, conductivity $(r=0.345)$ and $p H$ $(r=0.059)$, negative correlation was recorded between animal number and oxygen concentration $(r=-0.506)$. We caught 654 animals in all (348 males and 306 females; sex ratio was 1.14:1). The number of observed males and females fluctuated throughout the year according to their life cycle (Figure 4). There was no activity recorded when the temperature was below $3.1^{\circ} \mathrm{C}$ (January 2000). It seems that males were generally more active. Females were more active after hatching and before mating and therefore more frequently observed. The heaviest male was $55 \mathrm{~g}$ and the heaviest female was $38 \mathrm{~g}$. The longest male was $10.3 \mathrm{~cm}$ long and the longest female was $9.29 \mathrm{~cm}$ long. We found strong positive correlation between animal length and weight $(r=0.891)$. Freshly moulted animals (males and females without eggs) were caught for the first time on the $1^{\text {st }}$ of June, and for the last time at the beginning of October. 


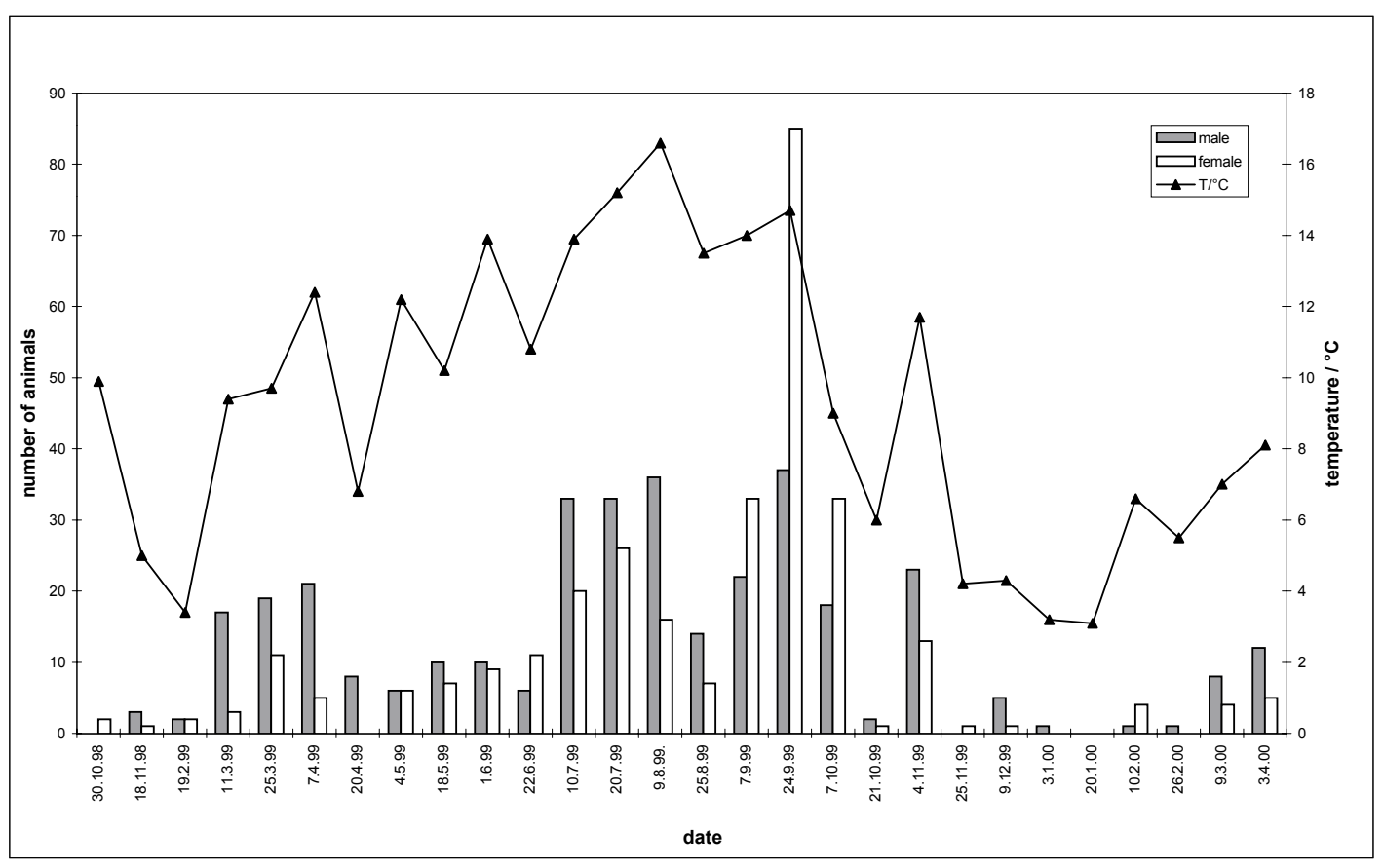

\section{Figure 4}

Relation between number of $\boldsymbol{A}$. torrentium caught in Kraljevec stream per month and water temperature.

\section{Figure 4}

Relation entre le nombre d'A. torrentium capturées par mois dans le ruisseau Kraljevec et la température.

Development of the glair glands in females started in August $\left(9^{\text {th }}\right)$, and mature testes were recorded at the beginning of September.

Yellow (internal) eggs were noticed for the first time on the $9^{\text {th }}$ of August, browngreen eggs on the $24^{\text {th }}$ of September and external eggs on the $4^{\text {th }}$ of November. On that occasion we also found spermatophores attached to the females abdomen. On the $22^{\text {nd }}$ of June we caught a female with eggs for the last time (Table II).

From 306 females trapped $48(15.7 \%)$ were found with eggs and $150(49 \%)$ with developed glair glands. The smallest female found with activated glair glands was $6.3 \mathrm{~cm}$ long and with pleopodal eggs was $6.34 \mathrm{~cm}$ long.

The mean diameter of pleopodal eggs was $2.80 \mathrm{~mm}$ (ranged from 2.4 to $3.6 \mathrm{~mm}$ ) and mean number of eggs per female was 53.58 (ranged from 1 to 104). A positive correlation existed between female length and the number of eggs $(r=0.426)$ and a negative one between number of eggs and their diametre $(r=-0.325)$.

$33.35 \%$ of population caught suffered from limb or cheliped loss, $8.409 \%$ had signs of burn spot disease and on $43.730 \%$ we found epibionts B. parasita (Figure 3). 


\section{MRZLAK STREAM}

We found positive correlations between the number of animals caught and water temperature $(r=0.663)$, water hardness $(r=0.373)$, conductivity $(r=0.366)$ and $\mathrm{pH}$ $(r=0.196)$, negative correlation was recorded between animal number and oxygen concentration $(r=-0.674)$.

We caught 731 animals in all (383 males and 348 females; sex ratio 1.1:1). The number of observed males and females fluctuated throughout year according to their life cycle (Figure 5). There was no activity recorded when temperature was below $2.9^{\circ} \mathrm{C}$ (January 2000). It seems that males were generally more active. Females were more active in May and at the end of the summer and therefore more frequently caught. The heaviest male was $48 \mathrm{~g}$ and the heaviest female was $35 \mathrm{~g}$. The longest male was $9.42 \mathrm{~cm}$ long and the longest female $9.28 \mathrm{~cm}$. We found a strong positive correlation between animals length and weight $(r=0.916)$.

Freshly moulted animals were caught, for the first time, in mid May $\left(14^{\text {th }}\right)$, and for the last time at the beginning of October.

Development of the glair glands in females started in mid July $\left(21^{\text {st }}\right)$, and mature testes were recorded at the beginning of October $\left(7^{\text {th }}\right)$.

Yellow (internal) eggs were noticed for the first time on the $10^{\text {th }}$ of August, browngreen eggs on the $27^{\text {th }}$ of September and external eggs on the $4^{\text {th }}$ of November. On that occasion we also found spermatophores attached to the females' abdomen. On the $22^{\text {nd }}$ of June we caught a female with hatched juveniles under her tail.

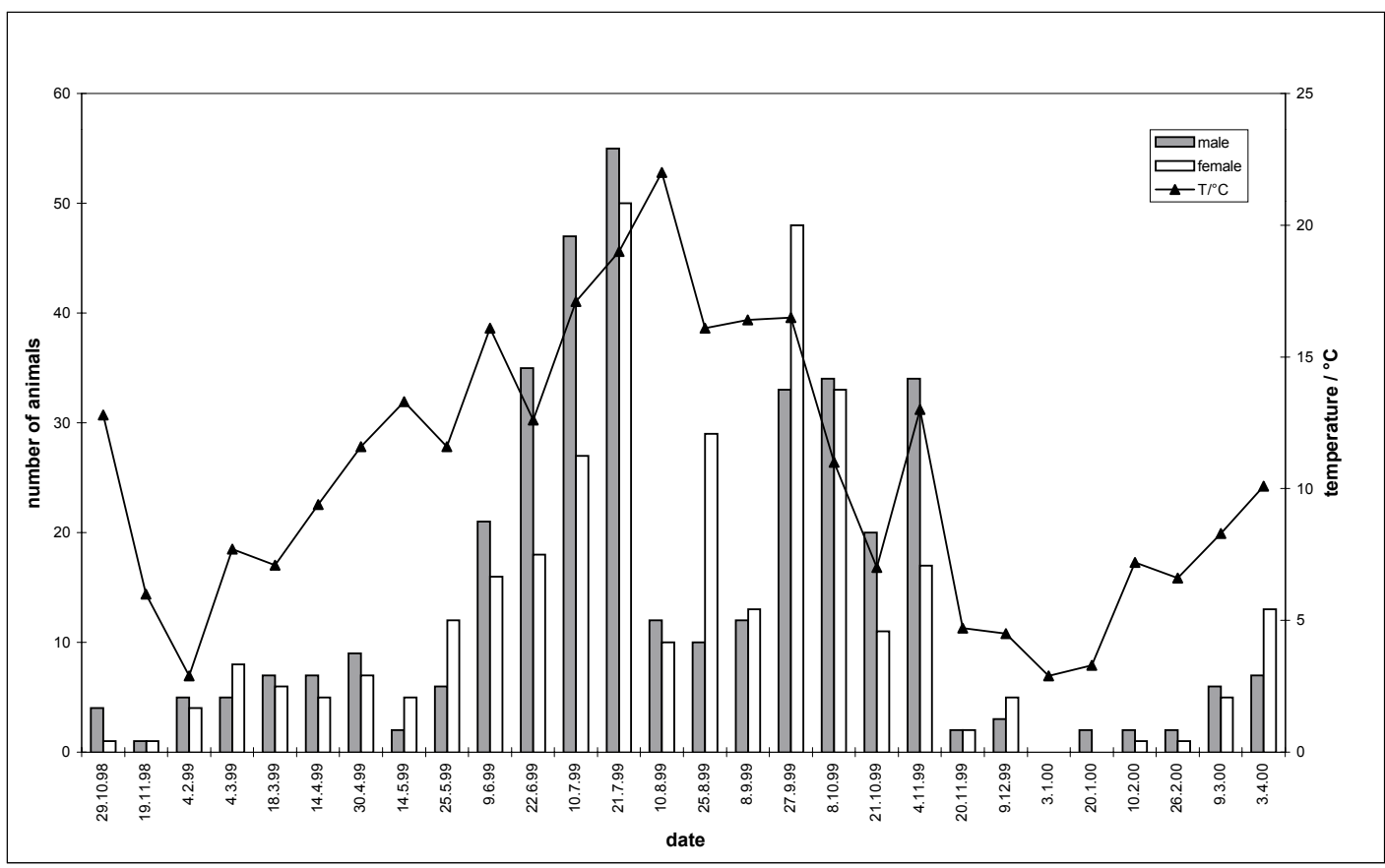

\section{Figure 5}

Relation between number of $\boldsymbol{A}$. torrentium caught in Mrzlak stream per month and water temperature.

\section{Figure 5}

Relation entre le nombre d'A. torrentium capturées par mois dans le ruisseau Mrzlak et la température. 
From 348 females trapped, $38(10.9 \%)$ were found with eggs and $70(20.1 \%)$ with developed glair glands. The smallest female caught with developed glair glands was $5.8 \mathrm{~cm}$ and with pleopodal eggs was $5.4 \mathrm{~cm}$ long.

The mean diameter of pleopodal eggs was $2.80 \mathrm{~mm}$ (ranged from 2.4 to $3.4 \mathrm{~mm}$ ) and mean number of eggs per female was 44.10 (ranged from 1 to 90). A positive correlation existed between female length and the number of eggs $(r=0.432)$ and negative one between number of eggs and their diametre $(r=-0.413)$.

$34.97 \%$ of population caught suffered from limb or cheliped loss, $4.23 \%$ had signs of burn spot disease and on $30.73 \%$ we found epibionts B. parasita (Figure 3 ).

\section{DISCUSSION}

A. torrentium has been sporadically studied in Croatia (OBRADOVIĆ, 1988). In Europe the situation studied is better but still unsatisfactory (BOHL, 1987a; TROSCHEL et al., 1995; PÖCKL, 1999; VORBUGER and RIBI, 1999; RENZ and BREITHAUPT, 2000).

The stone crayfish is a native species in Croatia. In this research analyses of crayfish activities throughout the year in Medvednica's streams was based on animals caught in traps, so the data reliability is dependent on the trappability of crayfish. ABRAHAMSSON (1983) considered that trappability is mainly related to food searching but might also fluctuate with a change in other factors such as light conditions, water temperature, etc.

The populations we studied in Mrzlak and Kraljevec stream are natural. These streams are situated on the outskirts of Zagreb on the southern, bottom slopes of Medvednica mountain. BOHL (1997) pointed out the importance of spatial continuity of suitable habitats for natural dispersion of crayfish. Both populations are completely isolated as their lower stretches are channalised and so natural spreading of animals over a wider area is disabled. Sarni stream population originates from stocking made by local hunters in 1970 (personal communication). That stream is not influenced by people and it is not isolated from other water courses (it is a tributary of a bigger stream). It is situated on the north slopes of Medvednica mountain, away from any human settlements.

Altitudal distribution of our populations ranges as follows: Sarni stream $250 \mathrm{~m}$, Kraljevec $400 \mathrm{~m}$ and Mrzlak $300 \mathrm{~m}$. In Europe, A. torrentium was recorded on the altitudes 310-820 m (BOHL, 1987a; RENZ and BREITHAUPT, 2000). According to BOHL (1987b) the stone crayfish has been driven from it's original lowland habitats into higher altitudes (90\% of natural stocks in Bavaria, Germany, are found at altitudes over $500 \mathrm{~m}$ above sea level) due to human impact. Sarni stream is away from human influence so the presence of stone crayfish on lower altitud was recorded, while lower parts of Kraljevec and Mrzlak are channalised and no crayfish was found.

Mean depths of our water courses were similar to those recorded for $A$. torrentium by BOHL (1987a): Sarni $34 \pm 19 \mathrm{~cm}$; Kraljevec $25 \pm 9 \mathrm{~cm}$; Mrzlak $20 \pm 16 \mathrm{~cm}$. Mean width of streams greatly varied during the year (from $0.5 \mathrm{~m}$ to $3 \mathrm{~m}$ ) and all three are situated in beech-chestnut forest with $90-100 \%$ surface of shorline shaded. Until now A. torrentium is described from streams whose width ranged from 0.5 to $50 \mathrm{~m}$, average $1-2 \mathrm{~m}$ (BOHL, 1987a; KAPPUS et al., 1999) and that are situated in the higher regions in woodland headwaters (PÖCKL, 1999) while the urbanised territories and channalised (even renaturated) streams lacked crayfish populations (KAPPUS et al., 1999).

All three streams offer plenty of hiding places (stones, tree roots) into which crayfish can retreat during the daylight hours and moulting periods so therefore we could say that studied streams present a good habitat for stone crayfish. It is known that crayfish 
presence (among other factors) is strongly dependent on the structure of the stream bottom (BOHL, 1987a; LAURENT, 1988) and higher population density is expected where greater morphometric and structural variability exists (BOHL, 1997).

The physical and chemical characteristics of the water are important factors influencing the crayfish's activities during the year. The oxygen concentration ranged from 6.70 to $14.49 \mathrm{mg} / \mathrm{l}$. Freshwaters with oxygen concentration over $4 \mathrm{mg} / \mathrm{l}$ are suitable for crayfish life (HOGGER, 1988). Recorded pH values and conductivity (Table I) are in accordance with literature data on freshwaters inhabited with crayfish (BOHL, 1987a). The calcium concentration in the water is an important environmental factor for crayfish (GREENAWAY, 1974). Alkalinity (expressed as $\mathrm{mg} \mathrm{CaCO}_{3} / \mathrm{I}$ ) varied from $50-200 \mathrm{mg} / \mathrm{l}$ and it is in accordance with literature data on stone crayfish (RENZ and BREITHAUPT, 2000). Maximal water temperature recorded for the stone crayfish habitats varied from $11^{\circ} \mathrm{C}$ to $26^{\circ} \mathrm{C}$ (BOHL, 1987a). In our streams water temperature fluctuated throughout the year from $1^{\circ} \mathrm{C}$ to $22^{\circ} \mathrm{C}$. In general average water temperature was the highest in Mrzlak, the lowest in Kraljevec and it fluctuated the most in Sarni (Table I). We found a positive correlation between the water temperature and the number of animals caught, but we could not say that crayfish activity was directly and only linked to water temperature (Figures 2, 4, 5, 6). In accordance with TROSCHEL et al. (1995) we found that the amount of activity in spring did not increase proportionally to the raise of the water temperature, but it seems likely that the rise of temperature in early spring was an initiator of their activity (Figure 6). Higher temperatures can rise an animal's locomotion and metabolic rates and it is likely that the trappability is greater at higher temperatures (ACKEFORS, 1999). In accordance to BOHL (1987a), and contrary to TROSCHEL et al. (1995), we did not record any activity when water temperature was below $6.2^{\circ} \mathrm{C}$ (Sarni), $3.1^{\circ} \mathrm{C}$ (Kraljevec) and $2.9^{\circ} \mathrm{C}$ (Mrzlak). The majority of crayfish were caught between June and November (78.79\% of individuals) when the temperature of the water was higher than $7^{\circ} \mathrm{C}$. We noticed, contrary to TROSCHEL et al. (1995) three peaks of activity (Figure 6). The first one in spring was probably connected with feeding behaviour, of males and females without eggs, after winter starvation, the second (June/July) as consequence of females joining in, after egg hatching had finished, and the third (September-beginning of November), according to our expectations and contrary to TROSCHEL et al. (1995) before and during the mating season. After $4^{\text {th }}$ of November, when we found the females with external eggs for the first time, activity significantly decreased, together with the water temperature, and it stayed low until the following spring. A small decrease in number of caught animals, after the peak in spring, could be the result of less active phase during the moulting period (males and females without eggs) and carrying the eggs (berried females) (LOWERY, 1988). Lower activity noticed in August, during the period when the water temperatures were at their highest, was probably due to high food availability (TROSCHEL et al., 1995).

Sex ratio in the catch for all three streams was around 1:1, but it varied all the year round. When we pooled data together, it could be seen that males outnumbered females (59\%, $41 \%$, respectively) in the period when females are seemingly inactive (from October until August of the following year - the egg carrying and moulting period) even though females activity increased from June (after egg hatching). Females outnumber males (58\%, $42 \%$, respectively) from August until the beginning of October. We suppose that females are more active during this period because they intensify feeding and preparations for mating.

The size of stone crayfish is smaller than the size of other European Astacidae. The recorded sizes for $A$. torrentium ranged from 6 to $9 \mathrm{~cm}$ (females) and from 8 to $10.5 \mathrm{~cm}$ (males) (LAURENT, 1988). During our research we recorded maximal length of $9.28 \mathrm{~cm}$ for females and $10.30 \mathrm{~cm}$ for males. The heaviest female $(38 \mathrm{~g})$ and the heaviest male $(55 \mathrm{~g})$ were caught from Kraljevec stream. Males' average weight was higher than females' average weight probably due to the bigger claws. 
The process of moulting is under control of several factors (nutritional status, light conditions, water temperature) and in a population it is normally synchronised, between adults, to avoid cannibalism (LOWERY, 1988). According to our data moulting in Sarni and Kraljevec started at the beginning of June, and in Mrzlak in the mid-May (Table II). We found freshly moulted both males and females without eggs. A slight delay in the start of moult for Sarni and Kraljevec is probably due to the fact that in Mrzlak the water temperature rose faster in spring. Soft-shelled stone crayfish were found until October when the temperature decreased to $10^{\circ} \mathrm{C}$ and when mating occurred.

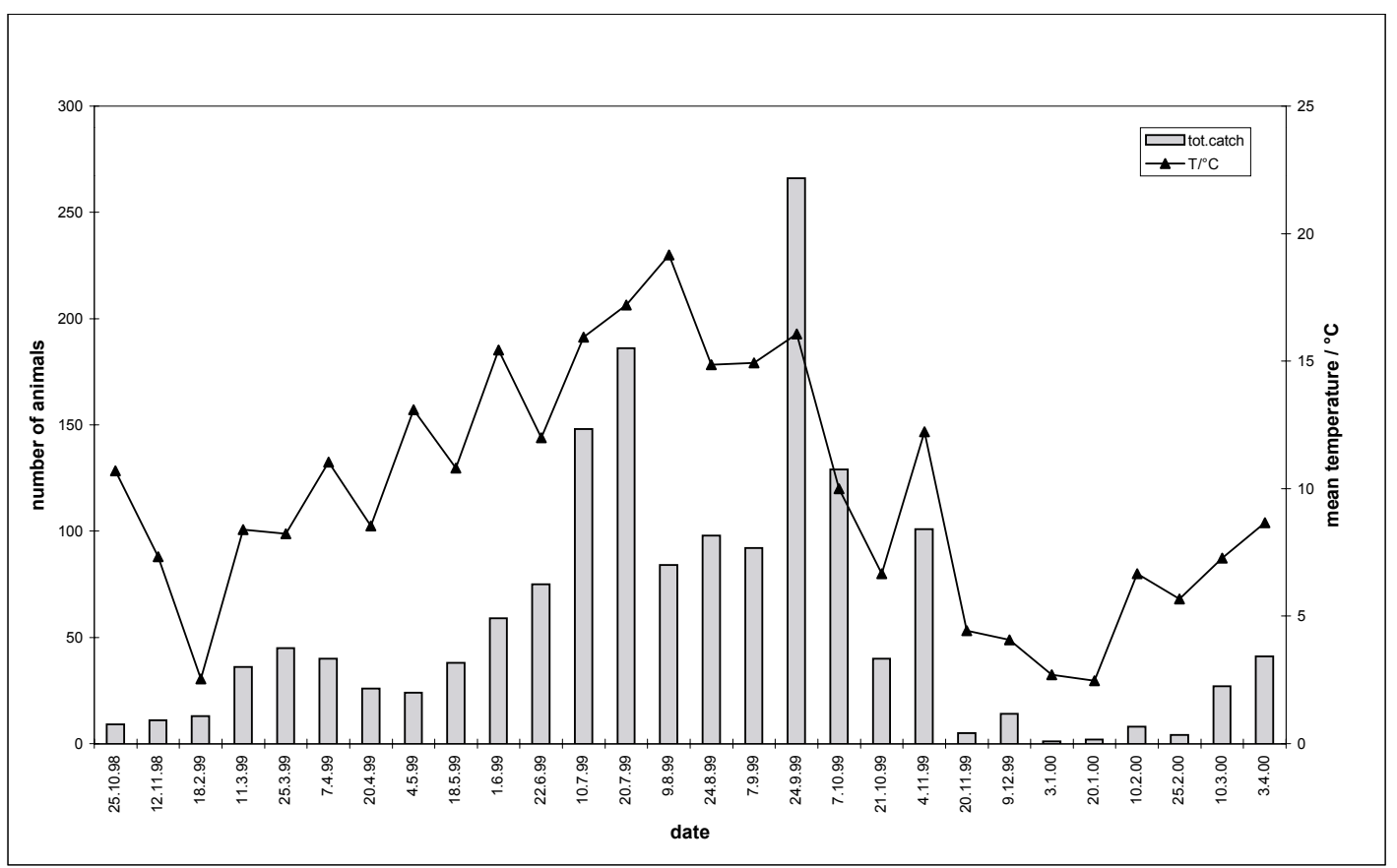

\section{Figure 6}

Total catch of $\boldsymbol{A}$. torrentium per month and mean water temperature (all data pooled together).

\section{Figure 6}

Capture totale de $\boldsymbol{A}$. torrentium et température moyenne (données agrégées).

The glair glands started to develop from the end of July (Mrzlak), e.g. the beginning of August (Kraljevec) and the end of August (Sarni) (Table II). The percentage of females prepared to mate varied from $20.1 \%$ to $49 \%$. According to ACKEFORS (1999) development of glair glands in Astacus astacus depend on the female's nutritional status. We suppose that stone crayfish follows the same pattern. As the females in Mrzlak started to develop glair glands first, we could say that the conditions in that stream support the fastest regaining of their nutritional status. The smallest female with developed glair glands was found in Mrzlak (5.8 cm long). The size of females prepared to mate (developed glair glands) in other populations was bigger $(6.08 \mathrm{~cm}$ and $6.30 \mathrm{~cm})$, but we noticed those females few weeks later so it might be possible that they moulted in the meantime.

In all three streams, on the $4^{\text {th }}$ of November we found, for the first time, females with external eggs and attached spermatophores, so it seems that mating and spawning took place at the end of October (between $20^{\text {th }}$ of October and $4^{\text {th }}$ of November). The percentage of berried females varied from $5.3 \%$ to $15.7 \%$ of total females caught. We suppose that 
catchability of egg-bearing females is lower and that recorded percentages underrepresented the real situation. The ovigerous females carried external eggs from early November until mid-June the following year (Table II). Hatching in our populations occurred a month earlier than in Germany (TROSCHEL et al., 1995) and the probable cause is geographical latitude.

In Germany, stone crayfish females may incubate 40 to 70 eggs (LAURENT, 1988). The maximal number of eggs per female we found was 104 (an average value was 53.56). The number of eggs per female greatly varied; there were females with less than 10 eggs, what is probably a consequence of egg loss. Berried females with just a few eggs were found before the hatching time (April-May) so that is in accordance with REYNOLDS (2002) statement that egg loss is progressive and small females rarely carry their eggs successfully to hatching so that date of observation is important. Possible reasons for egg loss could be poor egg attachment, disturbance, fungal infections, aggressive contacts with other crayfish (REYNOLDS, 2002). We found positive correlation between female total length and number of pleopodal eggs within all three populations and that is in accordance with the literature data (HUNER and LINDQUIST, 1991).

As BOHL (1997) pointed out, the proportion of damaged crayfish in a population could be an indicator of violation by predators. We did not find any traces of potential predators (fish, mammals) so we believe that recorded damages (mainly missing claws and legs or ruined uropods) are consequence of problems during moulting or aggressive behaviour during the mating period. We did not study diseases in details but we recorded external symptoms of burn spot disease in up to $22 \%$ of animals.

Presence of epibiont clitellat worm both on the animals and on the external eggs was quite common. Up to $44 \%$ of population was affected by $B$. parasita. It seems that $B$. parasita does not seriously harm stone crayfish so it is rather a commensal than a real parasite.

\section{CONCLUSION}

In north-west Croatia the stone crayfish could be found in cold, fast flowing streams. Comparing to European populations that are mostly restricted to upper courses of the drain systems, Croatian stone crayfish populations could be also found in lower parts of water courses thanks to still relatively low human impact onto their natural habitats.

In general, the populations we studied seemed to be in good condition - trapped animals were of different lengths (the smallest animal caught was $1.7 \mathrm{~cm}$ long) and they were all vigorous, showing good reactions. It seems that their habitat is favourable for their normal growth and development.

This is the first time that this type of research on $A$. torrentium has been done in Croatia and we hope to continue with it in the future. As, in general, there has been very little research made on the stone crayfish, we hope that our data will contribute to the knowledge about this small, native European species.

\section{ACKNOWLEDGEMENTS}

We greatly appreciate and we are grateful to Ivan Tonković and Branka Štefok for all the help during the field investigation. Our gratitude also goes to Adam Maguire and Martine Jurišić-Legrand for language corrections.

This work was supported by the Scientific Research Council of the Republic of Croatia within the framework of Project No. 119105. 


\section{REFERENCES}

ABRAHAMSSON S., 1983. Trappability, locomotion, and diel pattern of activity of the crayfish Astacus astacus and Pacifastacus leniusculus Dana. Freshwater crayfish, 5, 239-253.

ACKEFORS H.E.G., 1999. Observation on the yearly life cycle of Astacus astacus in a small lake in Sweden. Freshwater crayfish, 12, 413-429.

APHA, 1985. Standard methods for the examination of water and wastewater. $16^{\text {th }}$ ed. Amer. Publ. Health Assoc., New York.

BOHL E., 1987a. Comparative studies on crayfish brooks in Bavaria (Astacus astacus L., Austropotamobius torrentium Schr.). Freshwater crayfish, 7, 287-294.

BOHL E., 1987b. Crayfish stock and culture situation in Germany (FR). Crayfish culture in Europe, 87-91.

BOHL E., 1997. An isolated population of the white-clawed crayfish (Austropotamobius pallipes) in the principality of Liechtenstein. Bull. Fr. Pêche Piscic., 347, 701-712.

BOHL E., 1999. Crayfish stock situation in Bavaria (Germany) - attributes, threats and chances. Freshwater crayfish, 12, 765-777.

BUDIHNA N., 1991. Umetna inkubacija rakovih jajčec vrste Astacus astacus (L.). Ichthyos, 10, 1-17.

CAPELLI G.M., MAGNUSSON J.J., 1975. Reproduction, molting, and distribution of Orconectes propinquua (Girard) in relation to temperature in a north mesotrophic lake. Freshwater crayfish, 2, 415-427.

GREENAWAY P., 1974. Calcium balance at the postmoult stage of freshwater crayfish Austropotamobius pallipes (Lereboullet). J. Expe. Biol., 61, 35-48.

HOGGER J.B., 1988. Ecology, population biology and behaviour. In : HOLDICH D.M. and LOWERY R.S. (Eds.), Freshwater crayfish, 115-144, University Press, Cambridge.

HUNER J.V., LINDQVIST O.V., 1991. Special problems in freshwater crayfish egg production. In : WENNER A. and KURIS A. (Eds.) Crustacean egg production, 235-246, A.A. Balkema, Roterdam.

KAPPUS B., PEISSNER T., RAWER-JOST C., 1999. Distribution and habitat conditions of crayfish populations in the urban freshwater systems of Stuttgart (BadenWürttemberg, Germany). Freshwater Crayfish, 12, 778-785.

KARAMAN M., 1967. Branchiobdellidae Jugoslavije. Poseban otisak iz Zbornika Filozofskog fakulteta u Prištini. Knj. IV, 39-64.

LAURENT P.J., 1988. Austropotamobius pallipes and A. torrentium, with observations on their interactions with other species in Europe. In: HOLDICH D.M. and LOWERY R.S. (Eds.), Freshwater crayfish, 341-364, University Press, Cambridge.

LODGE D.M., HILL A.M., 1994. Factors governing species composition, population size, and productivity of cool-water crayfish. Nordic J. Freshw. Res., 69, 111-136.

LOWERY R.S., 1988. Growth, moulting and reproduction. In: HOLDICH D.M. and LOWERY R.S. (Eds.), Freshwater crayfish, 83-113, University Press, Cambridge.

MAGUIRE I., 2002. Porodica Astacidae u sjeverozapadnoj Hrvatskoj. Doctoral thesis, Faculty of Science, University of Zagreb.

NARODNE NOVINE, 30, 1994. Zakon o zaštiti prirode.

NARODNE NOVINE, 76, 1998. Pravilnik o zaštiti riječnih rakova.

OBRADOVIĆ J., 1988. Slatkovodni rakovi na tlu Jugoslavije - vrste, bolesti, uzgoj, zaštita. Ribarstvo Jugoslavije, 43, 55-59.

PÖCKL M., 1999. Distribution of crayfish species in Austria with special reference to introduced species. Freshwater Crayfish, 12, 733-750.

RENZ M., BREITHAUPT T., 2000. Habitat use of the crayfish Austropotamobius torrentium in small brooks and in Lake Constance, Southern Germany. Bull. Fr. Pêche Piscic., 356, $139-154$.

REYNOLDS J.D., 2002. Growth and reproduction. In : HOLDICH D.M. (ed.), Biology of freshwater crayfish, 152-191, Blackwell Science Ltd, Oxford. 
STUCKI T.P., ROMER J., 2001. Will Astacus leptodactylus displace Astacus astacus and Austropotamobius torrentium in Lake Ägeri, Switzerland? Aquat. sci., 63, 477-489.

ŠULGAJ A., 1937. Rak potočar i njegov uzgoj. In : BAUER M. (ed.), Monografija, Nova gradiška, $76 \mathrm{p}$.

TROSCHEL H.J., DEHUS P., 1993. Distribution of crayfish species in the federal republic of Germany, with special reference to Austropotamobius pallipes. Freshwater Crayfish, 9, 390-398.

TROSCHEL H.J., SCHULZ U., BERG R., 1995. Seasonal activity of stone crayfish Austropotamobius torrentium. Freshwater Crayfish, 10, 196-199.

VORBURGER C., RIBI G., 1999. Pacifastacus leniusculus and Austropotamobius torrentium prefer different substrats. Freshwater Crayfish, 10, 696-704. 